\title{
Vitamin D and the RNA transcriptome: more than mRNA regulation
}

\author{
Moray J. Campbell * \\ Department of Pharmacology and Therapeutics, Roswell Park Cancer Institute, Buffalo, NY, USA
}

\section{Edited by:}

Carsten Carlberg, University of Eastern Finland, Finland

\section{Reviewed by:}

Alberto Muñoz, Consejo Superior de Investigaciones Cientificas, Spain

Thomas William Dunlop, University of Eastern Finland, Finland

\section{*Correspondence:}

Moray J. Campbell, Department of Pharmacology and Therapeutics, Roswell Park Cancer Institute,

Buffalo, NY 14263, USA

e-mail: Moray.Campbell@

RoswellPark.org
The GRCh37.p13 primary assembly of the human genome contains 20805 protein coding mRNA, and 37147 non-protein coding genes and pseudogenes that as a result of RNA processing and editing generate 196501 gene transcripts. Given the size and diversity of the human transcriptome, it is timely to revisit what is known of VDR function in the regulation and targeting of transcription. Early transcriptomic studies using microarray approaches focused on the protein coding mRNA that were regulated by the VDR, usually following treatment with ligand. These studies quickly established the approximate size, and surprising diversity of the VDR transcriptome, revealing it to be highly heterogenous and cell type and time dependent. With the discovery of microRNA, investigators also considered VDR regulation of these non-protein coding RNA. Again, cell and time dependency has emerged. Attempts to integrate mRNA and miRNA regulation patterns are beginning to reveal patterns of co-regulation and interaction that allow for greater control of mRNA expression, and the capacity to govern more complex cellular events. As the awareness of the diversity of non-coding RNA increases, it is increasingly likely it will be revealed that VDR actions are mediated through these molecules also. Key knowledge gaps remain over the VDR transcriptome. The causes for the cell and type dependent transcriptional heterogenetiy remain enigmatic. ChIP-Seq approaches have confirmed that VDR binding choices differ very significantly by cell type, but as yet the underlying causes distilling VDR binding choices are unclear. Similarly, it is clear that many of the VDR binding sites are non-canonical in nature but again the mechanisms underlying these interactions are unclear. Finally, although alternative splicing is clearly a very significant process in cellular transcriptional control, the lack of RNA-Seq data centered on VDR function are currently limiting the global assessment of the VDR transcriptome. VDR focused research that complements publically available data (e.g., ENCODE Birney et al., 2007; Birney, 2012), TCGA (Strausberg et al., 2002), GTEx (Consortium, 2013) will enable these questions to be addressed through large-scale data integration efforts.

\section{Keywords: VDR, microRNA, transcriptome, epigenetic, microarray}

\section{THE TRANSCRIPTIONAL LANDSCAPE OF THE HUMAN GENOME}

An appreciation of the diversity of transcription across the human genome has undergone a rapid expansion in recent years, in large part thanks to the efforts of integrative genomic approaches such as those of ENCODE consortium (Birney, 2012; Maher, 2012; Stamatoyannopoulos, 2012; Rosenbloom et al., 2013). From these studies it has become apparent that there is considerable variation and diversity in; the distribution of transcription factor binding across the human genome; the interplay between transcription factors and different co-regulating partners; the extent of the genome that is transcribed; the number and functionally different RNA-based molecules that are transcribed, the impact of mechanisms that process and edit RNA molecules that generate even greater diversity of gene expression.

In this context it is timely to review the functions of the vitamin D receptor (VDR/NR1I1) (Pike et al., 1980; Baker et al., 1988; Carlberg and Campbell, 2013), and consider how its actions contribute to this diversity of transcriptional and post-transcriptional events.

\section{THE VDR ACTS IN MULTIMERIC PROTEIN COMPLEXES TO REGULATE TRANSCRIPTION}

The VDR, like many other members of the nuclear receptor superfamily are relatively well-understood transcription factors. Their actions have been dissected and modeled, and have generated the concept of cyclical gene regulation in which transcription factors oscillate between on and off states (Metivier et al., 2003; Reid et al., 2003; Kim et al., 2005; Vaisanen et al., 2005; Carroll et al., 2006; Meyer et al., 2006; Saramaki et al., 2006; Yang et al., 2006; Zella et al., 2006; Malinen et al., 2008; Seo et al., 2007).

A direct consequence of VDR genomic interactions and gene regulation is the control of the epigenetic states at receptor binding regions, and more broadly across target gene loci. Epigenetic events play a central role for transcriptional complexes and the various components in these multimeric complexes are able to 
initiate, sustain, and finally terminate transcription (Dobrzynski and Bruggeman, 2009). For example, different histone modifications can control the rate and magnitude of transcription (reviewed in Goldberg et al., 2007). These events are intertwined with levels of CpG methylation (Kangaspeska et al., 2008; Metivier et al., 2008; Le May et al., 2010). Thus the histone modifications regulated by VDR actions, and other epigenetic events including DNA methylation processes, combine during transcription to generate highly flexible chromatin states that are either transcriptionally receptive and resistant (Mohn and Schubeler, 2009). That is, the specific transcriptional potential of a gene is flexibly controlled by the combination of epigenetic events. These events are varied in space across the genomic loci, and in time through the course of the transcriptional cycle.

The diversity of histone modifications, and their association with different DNA functions formed the basis for the histone code hypothesis. This concept, first proposed in 1993, held that these modifications were governed in a coordinated manner and formed a code that mirrored the underlying DNA code to convey heritable information on transcription and expression (Turner, 1993). Given the rapid expansion of the understanding in the number of histone modifications, their genomic distribution and their combinatorial manner, it is only relatively recently that the true diversity of the range of histone states, and their functional outcomes, has become apparent (Goldberg et al., 2007). The strongest evidence that histone modifications at the level of metachromatin architecture form a stable and heritable "histone code," is perhaps seen with $\mathrm{X}$ chromosome inactivation (reviewed in Turner, 1998). The extent to which similar processes operate to govern the activity of micro-chromatin contexts at gene promoter regions, is an area of debate (Jenuwein and Allis, 2001; Turner, 2002).

The regulation of transcription and the patterns of mRNA expression have been related to the expression of these histone modifications through a wide range of correlative and functional studies. For example, histone H3 lysine 4 tri-methylation (H3K4me3) is found in the promoter regions of actively transcribed genes. This mark is mutually exclusive with $\mathrm{H} 3 \mathrm{~K} 9 \mathrm{me}$, which instead is associated with transcriptionally silent promoter regions. Acetylation of $\mathrm{H} 3 \mathrm{~K} 9$ is found along with methylation of $\mathrm{H} 3 \mathrm{~K} 4$ at active promoter regions. Similarly, H3K27 can be either acetylated or methylated, with acetylation associated with active gene transcription and methylation associated with gene silencing.

In many experimental cases it has been established that VDR activation by natural ligand $1 \alpha, 25$-dihydroxyvitamin D3 $\left(1 \alpha, 25(\mathrm{OH})_{2} \mathrm{D}_{3}\right)$ or synthetic analogs, can lead to a highly dynamic exchange of co-factors by releasing co-repressors and inducing a receptor conformation that attracts binding of coactivator proteins (Figure 1). This exchange of associations induces a more relaxed, or open, chromatin status and the recruitment of linking factors and subsequently the basal transcriptional machinery. However, this is not an indefinite signal and the ligand, is rapidly metabolized. Also the VDR itself is limited in function by proteasome-mediated receptor degradation (Peleg and Nguyen, 2010). In the absence of ligand, some basal level of receptor remains in the nucleus associated with co-repressor complex and leads to silencing of transcription (Malinen et al., 2008; Saramaki et al., 2009; Thorne et al., 2011; Doig et al., 2013). The sequencing, or choreography of these actions, give rise to the periodicity of transcriptional activation and pulsatile mRNA and protein accumulation and reflect intrinsic control mechanisms required to tightly regulate the expression of important signaling molecules. At closer resolution, for example on shorter time-scales, the patterns of regulation show some degree of coordinated pulsatile regulation, and probably reflect aspects of specific VDR binding sites impacting gene regulation for example through emerged to support chromatin looping within the same VDR target gene loci (Vaisanen et al., 2005; Saramaki et al., 2006, 2009).

Whilst these scenarios are relatively well characterized for the positive regulation of gene expression, it is probably not a complete understanding as the distribution of VDR binding in the genome (Ramagopalan et al., 2010; Heikkinen et al., 2011; Meyer et al., 2012; Ding et al., 2013) and the patterns of associated gene regulation suggest that the VDR is actually associated broadly with gene activation and repression. The mechanisms that drive gene repression appear more diverse than gene activation and reflect differences in complex formation, and the choreography of binding.

The patterns of protein-protein interaction identified for the VDR allude to both positive and negative gene regulation (Table 1). The VDR commonly forms a heterodimer with RXR $\alpha$ (Quack and Carlberg, 2000). However, the identification of partners that interact in the same complex supports a broad role for the VDR complex to regulate other signal transduction events and RNA processing activities.

A number of proteins with transcriptional activator function have been identified in complex with VDR. For example, $\mathrm{CBP} / \mathrm{p} 300$ is a transcriptional co-integrator with histone acetlyase activity (Wang et al., 2011a,b, 2013a) and is associated with the VDR. Other proteins such as SNW1/NCOA62 which has function as a transcriptional co-activator(Baudino et al., 1998), as well as other proteins that have more recently been characterized to have coativator function (CCND3) (Cenciarelli et al., 1999; Lazaro et al., 2002; Despouy et al., 2003; Sarruf et al., 2005). Similarly the corepressor HR is also identified by such protein-protein interactions (Hsieh et al., 2003).

Aside from these traditional roles to modulate transcriptional actions, there is evidence to support a wider range of actions for the VDR in the control of mRNA. The coactivator SNW1 also plays a role as a splicing factor. This latter function is also shared by another VDR interacting protein, namely SRPK1, which is a protein kinase that regulates the activity of various splicing factors (Hayes et al., 2006; Aubol et al., 2013). Other interactions allude to the cross-talk between the VDR and different signal transduction processes. For example, the VDR interacts with negative regulators of WNT signaling (NKD2) (Katoh and Katoh, 2007), substrates for PKC signaling (PRKCSH) (Gkika et al., 2004), p53 (Kommagani et al., 2006; Lambert et al., 2006; Maruyama et al., 2006; Saramaki et al., 2006; Ellison et al., 2008) and SMAD3 (Ding et al., 2013; Ito et al., 2013; Zerr et al., 2014). The VDR functionally interacts with a range of co-repressors such as NCOR1 (Saramaki et al., 2009; Doig et al., 2013), NCOR2/SMRT (Khanim 


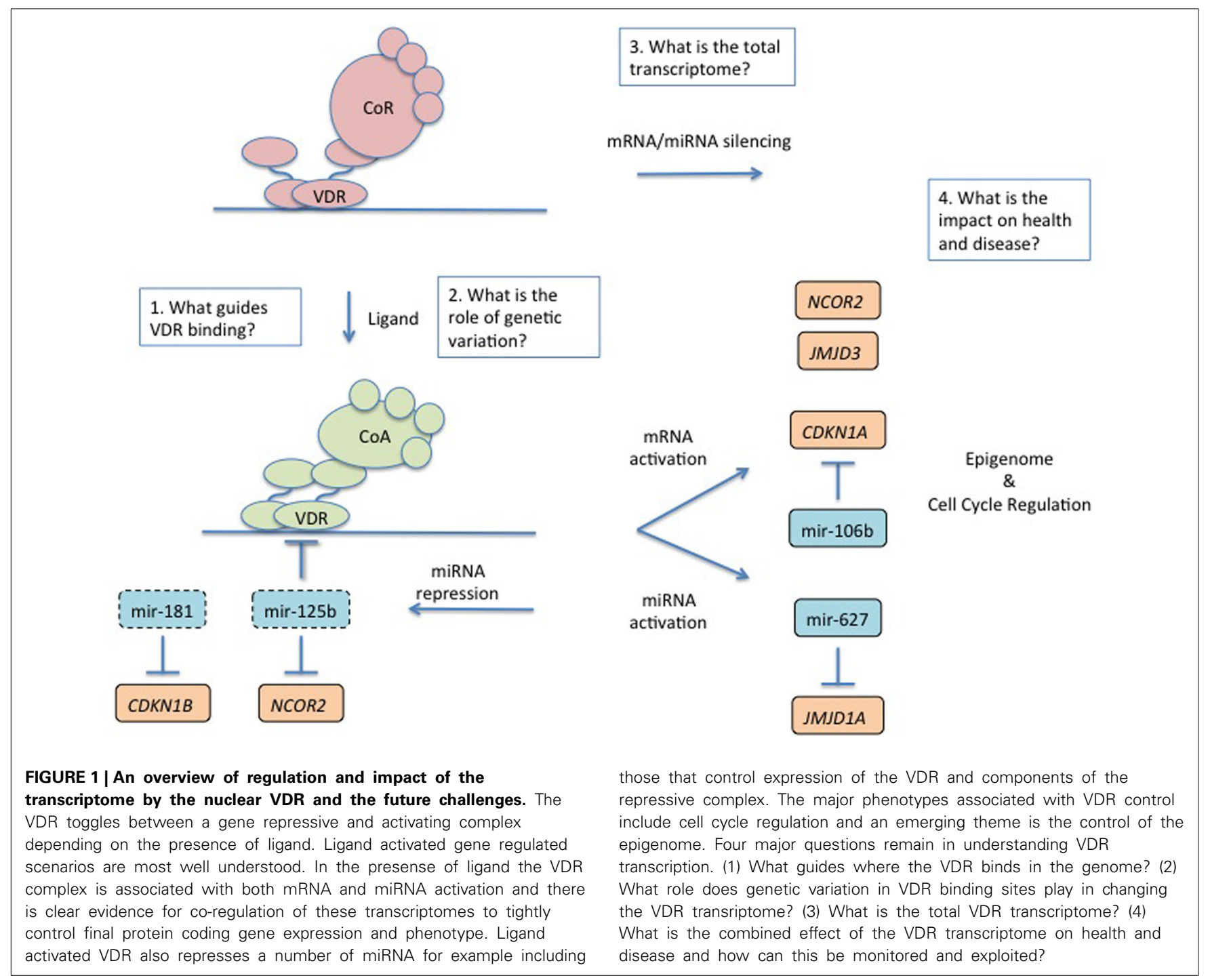

et al., 2004; Gynther et al., 2011), TRIP15/ALIEN (Polly et al., 2000; Cui et al., 2009) and DREAM (Scsucova et al., 2005) but, interestingly, agnostic protein-protein interaction tools such as INTACT (Table 1) have not identified direct VDR co-repressor interactions. It is unclear why these proteins are not identified in such protein-protein screens, but may reflect an experimental artifact as a result of investigators using ligand stimulated VDR to capture interacting proteins.

\section{THE DIVERSITY OF VDR-PROTEIN INTERACTIONS IS REFLECTED BY THE DISTRIBUTIONS OF GENOMIC BINDING SITES}

To identify VDR binding sites through the genome several groups have now applied ChIP-Seq approaches in different human cell types including immortalized lymphoblastoids (Ramagopalan et al., 2010), hepatic stellate cells (Ding et al., 2013) and cancer cell lines representing monocytic leukemia (Heikkinen et al., 2011) and colon cancer (Meyer et al., 2012). These studies also differed in the time of cell exposure to $1 \alpha, 25(\mathrm{OH})_{2} \mathrm{D}_{3}$ ranging from $40 \mathrm{~min}$ to $36 \mathrm{~h}$ identify binding sites, on the order of hundreds to several thousands of different binding sites depending on time of

treatment with $1 \alpha 25(\mathrm{OH})_{2} \mathrm{D}_{3}$ and cell background, with longer treatment time points tending to be associated with more binding sites. However, as yet there are not uniform standards for the analyses of NGS data, and therefore it is likely that different analytical approaches are influencing the number and significance of the VDR enriched peaks identified.

These differences in treatment and analytical approaches aside, these VDR binding data sets reveals that fewer than $20 \%$ of the VDR binding sites are in common between the different cell types. These finding perhaps offers strong support for the concept that VDR transcription is extremely tailored in different cell types, presumably through interactions with either equal or more dominant co-factors that combine to determine its binding. Another important finding from these studies is that the canonical binding site for the VDR, termed the direct repeat (DR) spaced by 3 nucleotides (DR-3), which was identified by traditional biochemical approaches in candidate gene studies, appears to be the minority genomic element that directly binds the receptor. Fewer that $30 \%$ of genomic VDR binding sites contain a DR3 , although this number is increased following ligand treatment 
Table 1 | Proteins known to interact with the VDR.

\begin{tabular}{|c|c|c|c|c|}
\hline Interacting protein & Function & Detection method & Interaction & Publication \\
\hline Retinoid $X$ receptor alpha $(R X R \alpha)$ & Transcription factor & Electron microscopy & Direct interaction & Orlov et al., 2012 \\
\hline Retinoid $X$ receptor beta $(R X R \beta)$ & Transcription factor & Two hybrid & Physical association & Wang et al., 2011a \\
\hline $\begin{array}{l}\text { E1A-associated protein p300 } \\
(\mathrm{CBP} / \mathrm{p} 300)\end{array}$ & Histone acetyltransferase & Two hybrid & Physical association & Wang et al., 2011a \\
\hline $\begin{array}{l}\text { Mediator complex subunit } \\
\text { (MED1) }\end{array}$ & $\begin{array}{l}\text { Mediator complex that binds basal } \\
\text { transcriptional machinery and } \\
\text { drives transcriptional initiation }\end{array}$ & Pull down & Physical association & Yuan et al., 1998 \\
\hline $\begin{array}{l}\text { Nuclear receptor coactivator } 6 \\
\text { (NCOA6) }\end{array}$ & $\begin{array}{l}\text { Transcriptional coactivator of } \\
\text { multiple nuclear receptors and } \\
\text { other transcription factors }\end{array}$ & Two hybrid & Physical association & $\begin{array}{l}\text { Mahajan and Samuels, } \\
2000\end{array}$ \\
\hline $\begin{array}{l}\text { CXXC-type zinc finger protein } 5 \\
\text { (CXXC5) }\end{array}$ & $\begin{array}{l}\text { Transcription factor co-regulator of } \\
\text { WNT signaling }\end{array}$ & Two hybrid & Physical association & Wang et al., 2011a \\
\hline Tumor Protein P53 (p53) & $\begin{array}{l}\text { Tumor suppressor protein } \\
\text { containing transcriptional } \\
\text { activation, DNA binding, and } \\
\text { oligomerization domains }\end{array}$ & $\begin{array}{l}\text { Fluorescence } \\
\text { microscopy }\end{array}$ & Co-localization & Stambolsky et al., 2010 \\
\hline $\begin{array}{l}\text { Protein naked cuticle homolog } 2 \\
\text { (NKD2) }\end{array}$ & $\begin{array}{l}\text { Antagonist of WNT via degradation } \\
\text { DVL }\end{array}$ & Two hybrid & Physical association & Wang et al., 2011a \\
\hline $\begin{array}{l}\text { SMAD family member } 3 \\
\text { (SMAD3) }\end{array}$ & Transcriptional effector of TGF $\beta$ & Pull down & Physical association & Leong et al., 2001 \\
\hline $\begin{array}{l}\text { SNW Domain containing } \\
1 \text { (SNW1) }\end{array}$ & $\begin{array}{l}\text { Co-activator function with known } \\
\text { roles as a splicing factor }\end{array}$ & Two hybrid & $\begin{array}{l}\text { Physical association and } \\
\text { co-localization }\end{array}$ & $\begin{array}{l}\text { Baudino et al., 1998; } \\
\text { Zhang et al., } 2003\end{array}$ \\
\hline SFRS protein kinase 1 (SRPK1) & $\begin{array}{l}\text { Serine/arginine protein kinase } \\
\text { specific for the SR } \\
\text { (serine/arginine-rich domain) family } \\
\text { of splicing factors }\end{array}$ & Protein kinase assay & Phosphorylation reaction & Varjosalo et al., 2013 \\
\hline $\begin{array}{l}\text { Protein kinase } \mathrm{C} \text { substrate } 80 \\
\mathrm{~K}-\mathrm{H}(\mathrm{PRKCSH})\end{array}$ & Substrate for protein kinase $\mathrm{C}$ & Two hybrid & Physical association & Wang et al., 2011a \\
\hline $\begin{array}{l}\text { Protein-tyrosine phosphatase } \\
\text { H1(PTPN3) }\end{array}$ & $\begin{array}{l}\text { Protein tyrosine phosphatase that } \\
\text { regulate a variety of cellular } \\
\text { processes }\end{array}$ & Pull down & Physical association & Zhi et al., 2011 \\
\hline Complement Factor $\mathrm{H}(\mathrm{CFH})$ & $\begin{array}{l}\text { Regulator of complement } \\
\text { activation (RCA) gene cluster and } \\
\text { plays a role in the defense } \\
\text { mechanism to microbial infections }\end{array}$ & Two hybrid & Physical association & Wang et al., 2011a \\
\hline$\beta$-catenin & $\begin{array}{l}\text { Dual function protein, regulating } \\
\text { the coordination of cell-cell } \\
\text { adhesion and gene transcription. }\end{array}$ & Co-localization & Functional interaction & Pálmer et al., 2001 \\
\hline $\begin{array}{l}\text { Prolylcarboxypeptidase } \\
\text { (Angiotensinase C) (PRCP) }\end{array}$ & $\begin{array}{l}\text { A lysosomal } \\
\text { prolylcarboxypeptidase, which } \\
\text { cleaves C-terminal amino acids } \\
\text { linked to proline }\end{array}$ & Two hybrid & Physical association & Wang et al., 2011a \\
\hline Cyclin D3 (CCND3) & $\begin{array}{l}\text { Cyclin associated with control of } \\
\text { cell cycle and known co-factor for } \\
\text { several nuclear receptods }\end{array}$ & Two hybrid & Physical association & Wang et al., 2011a \\
\hline
\end{tabular}


Table 1 | Continued

\begin{tabular}{lllll}
\hline Interacting protein & Function & Detection method & Interaction & Publication \\
\hline Hair growth associated (HR) & $\begin{array}{l}\text { Transcriptional corepressor of } \\
\text { multiple nuclear receptors }\end{array}$ & Pull down & Direct interaction & Hsieh et al., 2003 \\
\hline Nuclear corepressor 1 (NCOR1) & Transcriptional corepressor & Two hybrid & Physical association & Tagami et al., 1998 \\
\hline Nuclear corepressor 2 (NCOR2) & Transcriptional corepressor & Immunoprecipitation & Physical association & Kim et al., 2009 \\
\hline $\begin{array}{l}\text { COP9 signalosome subunit 2 } \\
\text { (COPS2) }\end{array}$ & $\begin{array}{l}\text { Transcriptional corepressor and } \\
\text { component of the ubiquitin } \\
\text { conjugation pathway }\end{array}$ & Two hybrid & Physical association & \\
\hline
\end{tabular}

The INTACT database curated by EBI http://www.ebi.ac.uk/intact/ was interrogated for interactions with the VDR. Interactions of VDR with NCOR1, NCOR2, and COPS2 were curated from the literature.

when there is increased enrichment for VDR binding to DR-3 elements (reviewed in Carlberg and Campbell, 2013). Nonetheless, a range of other genomic elements were enriched in VDR binding peaks suggesting that the VDR co-operates closely with other factors to associate with the genome, both in the absence and presence of ligand. Indeed, the study of Evans and co-workers in the hepatic stellate cells (Ding et al., 2013) and the work of Pike and co-workers in colon cancer cells (Meyer et al., 2012) both address this significant cross-talk of the VDR. In the case of the hepatic cells this is considered in the context of TGF ${ }^{\circledR}$ and in the case of colon cancer cells this is with TCF4, downstream of ${ }^{\circledR}$-catenin. Both of these studies therefore reflect the finding of VDR interactions with SMAD3 specifically, and more generally with regulators of WNT signaling (Table 1).

\section{THE HUNT FOR PIONEER FACTORS TO EXPLAIN THE DIVERSITY OF VDR FUNCTION}

Together these ChIP-Seq studies suggest that the VDR combines with other proteins in a network of interactions, quite likely in a cell type specific manner, to participate in diverse gene regulatory networks. It remains to be established how targeted or stochastic this is. The variation observed in both the type and position of binding sites for the VDR, depending on cell phenotype and disease state, suggests it is directed, and at least will establish a paradigm for hypothesis testing concerning what directs the VDR to bind and participate in gene transcription. The specificity of VDR signaling may arise due to integration with other perhaps more dominant transcription factors. Again, for other nuclear receptors (e.g., AR and ER) the concept has emerged that receptor binding is guided by the actions of more dominant so-called pioneer factors including the Forkhead (FKH) family members (Lupien et al., 2008; Serandour et al., 2011; Sahu et al., 2013). Efforts to define the major pioneer factors for the VDR have proved to be less consistent between the different VDR ChIP-Seq studies and may reflect the biology of the VDR which, given that it exists in the nucleus both in the presence and absence of ligand, potentially is a more interactive protein such that a single dominant pioneer factor is not so deterministic.

Another approach to identify the interacting partners of the VDR has been to examine the gene networks it regulates and to cluster genes by known regulating transcription factors.
Novershtern et al. (2011) measured the transcriptome profiles of a large number of hematopoietic stem cells, multiple progenitor states and terminally differentiated cell types. They found distinct regulatory circuits in both stem cells and differentiated cells, which implicated dozens of new regulators in hematopoiesis. They identified 80 distinct modules of tightly co-expressed genes in the hematopoietic system. One of these modules is expressed in granulocytes and monocytes and includes genes encoding enzymes and cytokine receptors that are essential for inflammatory responses. Major players in this module are VDR together with the factors CEBP $\alpha$ and SPI1/PU.1. This indicates that VDR works together with this small set of transcription factors, in order to regulate granulocyte and monocyte differentiation. It is reasonable to anticipate that such modules exist in multiple cell types but are guided by the tissue specific expression of such factors.

\section{VDR REGULATION OF THE PROTEIN-CODING TRANSCRIPTOME}

Anti-proliferative effects of $1 \alpha, 25(\mathrm{OH})_{2} \mathrm{D}_{3}$ have been demonstrated in a wide variety of cancer cell lines, including those from prostate, breast, and colon (Colston et al., 1982, 1989; Peehl et al., 1994; Campbell et al., 1997; Koike et al., 1997; Elstner et al., 1999; Welsh et al., 2002; Pálmer et al., 2003). Following on from these, VDR transcriptional studies were initially undertaken at the candidate level to identify processes by which the VDR mediated its cellular effects. These approaches identified of the gene encoding the $1 \alpha, 25(\mathrm{OH})_{2} \mathrm{D}_{3}$ metabolizing enzyme CYP24A1 (Dwivedi et al., 2000; Anderson et al., 2003) and CDKN1A (encodes p21 $1^{(\text {waf1/cip1) }}$ ) (Schwaller et al., 1995) as VDR targets. Subsequently, with the emergence of differential expression and membrane array technology, workers applied these wider screening approaches to identify multiple genes regulated by the VDR. For example, Freedman and colleagues applied differential expression approaches in the context of $1 \alpha, 25(\mathrm{OH})_{2} \mathrm{D}_{3}$ induced myeloid differentiation and identified a number of cyclin dependent kinase inhibitors including CDKN1A and undertook functional confirmation studies to suggest the importance of the regulation of these targets to trigger myeloid differentiation (Liu et al., 1996). Others undertook so-called focused array technology whereby cDNA probes for selected genes involved in key biological processes or disease states were arranged on macro scale membrane arrays. Such arrays contained anywhere from several 
hundred to several thousand probes, and so were not genomewide in terms of coverage but rather were candidate arrays often focused around specific pathways or disease states such as cancer. Despite the limitations, these approaches yielded important information supporting the links between VDR action and the regulation of growth and signaling (Savli et al., 2002). Similarly, first generation arrays chips, for example from Affymetrix which contained 4500 probes (Akutsu et al., 2001), also enabled sufficient genomic coverage to begin to define specific regulated gene networks. This particular study from White (Akutsu et al., 2001) and co-workers identified 38 genes that were responsive to $1 \alpha, 25(\mathrm{OH})_{2} \mathrm{D}_{3}$ exposure, which represented approximately $1 \%$ of the transcriptome studied, and included GADD45A. These earlier studies already suggested at the footprint of the VDR dependent transcriptome (reviewed in Rid et al., 2013). In many ways these studies highlighted the heterogeneity of VDR actions that was to be identified subsequently by ChIP-Seq studies. This heterogeneity may in part reflect experimental conditions with very different cell line differences, and genuine tissue-specific differences of cofactor expression that alter the amplitude and periodicity of VDR transcriptional actions.

Even within this diversity there is some consistency on a certain targets and the biological actions they relate to, including cell cycle regulation (Akutsu et al., 2001; Pálmer et al., 2003; Eelen et al., 2004; Wang et al., 2005). A common anti-proliferative VDR function is associated with arrest at $G_{0} / G_{1}$ of the cell cycle, coupled with up-regulation of a number of cell cycle inhibitors. Candidate promoter characterization studies have demonstrated a series of VDR binding sites in the promoter/enhancer region of CDKN1A (Liu et al., 1996; Saramaki et al., 2006). By contrast the regulation of the related CDKI p $27^{(k i p 1)}$ is mechanistically enigmatic, and included translational regulation and enhanced mRNA translation, and attenuating degrading mechanisms (Hengst and Reed, 1996; Wang et al., 1996; Huang et al., 2004; Li et al., 2004). The up-regulation of $\mathrm{p} 21^{\text {(waf1/cip1) }}$ and $\mathrm{p} 27^{\text {(kip } 1)}$ principally mediate $\mathrm{G}_{1}$ cell cycle arrest, but $1 \alpha, 25(\mathrm{OH})_{2} \mathrm{D}_{3}$ has been shown to mediate a $\mathrm{G}_{2} / \mathrm{M}$ cell cycle arrest in a number of cancer cell lines via direct induction of GADD45A (Akutsu et al., 2001; Jiang et al., 2003; Khanim et al., 2004).

In the transition to genome wide understanding, workers applied more comprehensive array approaches to define VDR mRNA transcriptomes. For example, investigations of squamous cells (Lin et al., 2002; Wang et al., 2005) identified networks of genes that trigger the response to wounding, protease inhibition, secondary metabolite biosynthesis, cellular migration, and amine biosynthetic processes. Another approach has been to examine vitamin $\mathrm{D}$ sensitive and responsive isogenic cell pairs and undertake analyses to identify key networks that are critical for mediating antiproliferative sensitivity toward $1 \alpha 25(\mathrm{OH})_{2} \mathrm{D}_{3}$. In this manner a critical role for $\mathrm{TGF}^{\circledR}$ signaling was again revealed, to associate with VDR antiproliferative sensitivity toward $1 \alpha 25(\mathrm{OH})_{2} \mathrm{D}_{3}$ in breast cancer cell models (Towsend et al., 2006). Exploiting leukemia cell models with differential responsiveness toward $1 \alpha 25(\mathrm{OH})_{2} \mathrm{D}_{3}$ triggereddifferentiation (Tagliafico et al., 2006) identified that certain VDR transcriptional targets could distinguish the aggressiveness of the leukemia, again, focused around cell cycle and included MS4A3 which can modulate the phosphorylation of CDK2 and therefore exert control over the cell cycle. This concept of VDR sensitive vs. resistant models was also exploited in prostate cancer to identify the critical VDR transcriptional targets that mediate antiproliferative sensitivity and again also identified cell cycle and signal transduction components including GADD45A and $M A P K A P K 2$ that were required to mediate the sensitivity of cells to $1 \alpha, 25(\mathrm{OH})_{2} \mathrm{D}_{3}$. Furthermore, these studies examined the epigenetic basis for the transcriptionally inert state of these targets in resistant models (Rashid et al., 2001; Khanim et al., 2004).

Identification of the VDR-dependent transcriptome using microarray approaches is heavily dependent on a range of statistical and technical considerations (Do and Choi, 2006; Zhang et al., 2009) including hybridization variations and limitations, background effects, normalization procedures, the choice of statistical test to identify differentially expressed genes, which in turn relies on study design and the numbers of arrays and samples chosen for study. Many of these study components were only formally agreed upon with the establishment of the MIAME compliant protocols in 2001 (Brazma et al., 2001), and as these became accepted standards for journal publication these approaches became widespread through the biological community.

MIAME compliant array experiments are subsequently published in public archives, such as GEO (Barrett et al., 2005, 2013) and ArrayExpress at EMBL (Parkinson et al., 2007) and Stanford microarray database (Marinelli et al., 2008). These three repositories between them contain thousands of genome-wide microarray experiments, containing millions of individual microarrays. Mining these repositories reveals a range of experiments (not all published) where cells have been treated with $1 \alpha, 25(\mathrm{OH})_{2} \mathrm{D}_{3}$ and other vitamin D compounds, and RNA effects studied between short time points $(1-2 \mathrm{~h})$ to several days (Table 2 ). Again, these studies have supported consistent themes in terms of the VDRmediated control of cell cycle and signal transduction processes, the suppression of WNT and NF- $\mathrm{B}$, and the regulation of IGF1 signaling (Kovalenko et al., 2011), and integrated actions with TGF ${ }^{\circledR}$ signaling. A final area to emerge from these agnostic studies of the VDR transcriptome is the impact that $1 \alpha 25(\mathrm{OH})_{2} \mathrm{D}_{3}$ exposure exerts on a range of chromatin remodeling components. Interestingly, NCOR2/SMRT appears to be a target of VDR signaling (Dunlop et al., 2004), and adds to the concept that VDR signaling is cyclical and based on the functions of various negative feedback loops. Similarly, KDM6B/JMJD3 is a histone H3 lysine demethylase and expression is induced by the activated VDR. In this manner, VDR action can feed-forward its own transcriptional program by promoting $\mathrm{H} 3 \mathrm{~K} 9$ acetylation and gene action (Pereira et al., 2011).

Given the number of arrays available, it is now timely to consider meta-analyses across the arrays to reveal common themes; this forward compatibility is one the key benefits of MIAME compliance. Meta-integration of array data has been shown to be surprisingly revealing in a range of studies. For example at the larger scale various workers have integrated multiple microarray data to reveal underlying patterns in the context of disease classification (Shah et al., 2009; Engreitz et al., 2011) but can also be applied to consider that specific phenotypes (MartinezCliment et al., 2010; Rantala et al., 2010; Lai et al., 2014). It is 
Table 2 | Publically available MIAME compliant microarray studies of VDR function.

\begin{tabular}{|c|c|c|}
\hline Experimental title/design & $\begin{array}{l}\text { GEO series accession } \\
\text { number }\end{array}$ & Publication \\
\hline \multicolumn{3}{|l|}{ PROTEIN CODING MRNA } \\
\hline Vitamin D effect on bronchial smooth muscle cells & GSE5145 & Bosse et al., 2007 \\
\hline $\begin{array}{l}\text { Genome-wide analysis of vitamin D receptor (VDR) target genes in THP-1 monocytic leucemia } \\
\text { cells }\end{array}$ & GSE27270 & Heikkinen et al., 2011 \\
\hline $\begin{array}{l}\text { Transcriptional effects of 1,25 dihydroxi-vitamin D3 physiological and supra-physiological } \\
\text { concentrations in breast cancer organotypic culture }\end{array}$ & GSE27220 & \\
\hline $\begin{array}{l}\text { Analysis of vitamin D response element binding protein target genes reveals a role for vitamin } \\
\text { D in osteoblast mTOR signaling }\end{array}$ & GSE22523 & Lisse et al., 2011 \\
\hline $\begin{array}{l}\text { Expression profiling of androgen receptor and vitamin D receptor mediated signaling in } \\
\text { prostate cancer cells }\end{array}$ & GSE17461 & Wang et al., 2011b \\
\hline Understanding vitamin D resistance using expression microarrays & GSE9867 & Costa et al., 2009 \\
\hline Effects of TX527, a hypocalcemic vitamin D analog on human activated T Iymphocytes & GSE23984 & Baeke et al., 2011 \\
\hline $\begin{array}{l}\text { Transcriptome profiling of genes regulated by } \mathrm{RXR} \text { and its partners in monocyte-derived } \\
\text { dendritic cells }\end{array}$ & GSE23073 & Szeles et al., 2010 \\
\hline \multicolumn{3}{|l|}{ NON-PROTEIN CODING RNA } \\
\hline MicroRNA-22 upregulation by vitamin D mediates its protective action against colon cancer. & GSE34564 & Alvarez-Diaz et al., 2012 \\
\hline $\begin{array}{l}\text { miRNA profiling of androgen receptor and vitamin D receptor mediated signaling in prostate } \\
\text { cancer cells }\end{array}$ & GSE23814 & Wang et al., 2013b \\
\hline Identification of miRNAs regulated by vitamin D within primary human osteoblasts & GSE34144 & \\
\hline Vitamin D and microRNA expression & GSE20122 & \\
\hline
\end{tabular}

therefore timely for these data to mined, and integrated with related nuclear receptor actions or other transcription factors that appear to co-operate with the VDR, for example SMADs.

\section{VDR REGULATION OF NON-CODING RNA SPECIES}

The human genome project in many ways was a race to define the protein coding genes within the human genome. Bacterial artificial chromosomes (BAC) clones enabled relatively large pieces of DNA, upto $300 \mathrm{~kb}$ to be inserted for sequencing (Osoegawa et al., 2000). However, a key step in the initial alignment process was to leverage cDNA and EST libraries and therefore naturally steered workers to protein coding genes, and the significance and extent of non-protein coding RNA remained largely unexplored.

Although non-coding RNA forms were well described in terms of ribosomal function it was little understood beyond this. The interpretation of the human genome, and other large scale approaches to investigating chromosomal function (Consortium et al., 2007; Tress et al., 2007) all led to a growing awareness of the extent of non-coding RNA and at least suggested that their was an unknown. This uncertainty has been reflected in the debate within the biological community over the extent and roles of so-called Junk DNA (Kapranov and St Laurent, 2012; Doolittle, 2013). As a result researchers have considered roles for non-coding RNA in the regulation of cell function and have begun to examine the interplay between the at least 20 different types of different non-coding RNA (reviewed in Ling et al., 2013). Many of these RNA species are gene regulatory RNA and include microRNA (miRNA), long non-coding RNA (long ncRNA), whereas others are involved in the posttranscriptional modification of RNA for example small nucleolar RNA (snoRNA).
Workers have now principally examined miRNA regulation by the VDR and evidence has emerged to support a role for the VDR to control regulation. For example Studzinski and coworkers revisited the mechanistically enigmatic VDR-mediated control p27 ${ }^{(k i p 1)}$. They elegantly demonstrated a role for VDR to down-regulate miR181a, which when left unchecked degrades p27 ${ }^{(k i p 1)}$ (Wang et al., 2009) (Figure 1). Thus, indirectly, VDR activation elevates expression of $\mathrm{p} 27^{(k i p 1)}$, initiates cell cycle arrest and commits cells toward differentiation. These studies illuminated the earlier ones that suggested that $\mathrm{p} 27^{(k i p 1)}$ protein levels appeared to be regulated by a range of post-transcriptional mechanisms, such as enhanced mRNA translation, and attenuating degradative mechanisms (Hengst and Reed, 1996; Huang et al., 2004; Li et al., 2004). Similar integration of miRNA and mRNA was revealed to control the regulation of CDKN1A. Dynamic patterns of CDKN1A mRNA accumulation have been observed in various cell systems (Thorne et al., 2011). This is in part explained by the epigenetic state of different VDR binding sites on the CDKN1A promoter. However, VDR-dependent co-regulation of miR-106b also appears to modulate the precise timing of CDKN1A accumulation and expression of $\mathrm{p} 21^{\text {(wafl/cip1) }}$ in a feedforward loop and determine the final extent of the cell cycle arrest. $1 \alpha, 25(\mathrm{OH})_{2} \mathrm{D}_{3}$ regulates the DNA helicase MCM7 (Khanim et al., 2004) that encodes the miR-106b, in intron 13 of the MCM7 gene, and together these co-regulation processes control p $21^{\text {(waf1/cip1) }}$ through the balance of MCM7 and CDKN1A (Saramaki et al., 2006; Ivanovska et al., 2008) (Figure 1).

MicroRNA (miRNA) contribute negative regulatory aspects to normal gene regulation, for example as part of feed-forward loop motifs (Mangan and Alon, 2003; Mangan et al., 2006). The co-regulation of mRNA and miRNA in motifs that included 
feed forward structures appears quite common (Song and Wang, 2008; Gatfield et al., 2009; Ribas et al., 2009; Sun et al., 2009; Wang et al., 2009). Other established miRNA targets of the VDR include miR-627 (Padi et al., 2013) that in turn targets JMJD1A (another histone H3 lysine demethylase) miR-98 (Ting et al., 2013) and let-7a-2 (Guan et al., 2013). However, one of the more explored relationships between VDR and miRNA is the relationship between VDR and miR-125b. MiR-125b inhibits VDR (Mohri et al., 2009; Zhang et al., 2011) and in turn VDR can down-regulate miR-125b (Iosue et al., 2013; Zhou et al., 2014), and the other targets of miR-125b include NCOR2/SMRT (Yang et al., 2012) (itself a VDR target gene) suggesting multiple levels of co-regulation and interdependent relationship between the VDR, and the mRNA and miRNA transcriptomes, and the epigenome. Finally, it is interesting to note that altered levels of miRNA are associated with cancer states and progression risks and indeed $\mathrm{miR}-125 \mathrm{~b}$ is associated with aggressive prostate cancer (Shi et al., 2011; Amir et al., 2013; Singh et al., 2014).

Beyond these candidate studies, a number of investigators have undertaken miRNA microarray analyses (Table 2) and these approaches have identified various networks, including the control of lipid metabolism and $\operatorname{PPAR}^{\odot}$ function (Wang et al., 2013b). It is likely that with the increased application of array approaches and next gen sequencing approaches will identify the key networks downstream of the VDR miRnome. This is unfortunately a more challenging research question owing to the many-to-many nature of miRNA; a given miRNA target many mRNA, and a given mRNA may have many miRNA targeting it. Thus, the computational challenges to resolve these relationships are not insignificant. Together these findings suggest that co-regulated miRNA may form an integral part of VDR signaling to control gene expression.

Of the other types of non-coding RNA, their regulation by VDR remains far less explored. Recently the group of Bickle have begun to dissect VDR regulation of IncRNA in keratinocytes and identified a number of target lncRNA and in doing so have raised the curtain on new avenues of exploration (Jiang and Bikle, 2014).

\section{CONCLUSIONS AND FUTURE CHALLENGES FOR UNDERSTANDING THE VDR TRANSCRIPTOME WHAT ARE THE PROTEINS, OR PROCESSES THAT GUIDE WHERE THE VDR BINDS IN THE GENOME?}

It is unclear what key pioneer factors will be identified and if the VDR is in a strong relationship with a specific family of pioneer factors, in the same that the AR is profoundly influenced by the Forkhead family members. Indeed, the precise pioneer factor may even be tissue specific as also revealed for the AR (Pihlajamaa et al., 2014). This may reflect the fact the ligand activation of the VDR is more associated with re-distribution of the VDR through the genome, rather than triggering movement into the nucleus (as in the case of the classic steroid hormone receptors).

The specific epigenetic niche that characterizes the VDR binding may also be revealing of where and why the VDR binds to the genome. These analyses will require agnostic integration of multiple genomic data sets, for example histone modifications, transcription factor binding, chromatin conformation and transcriptomic data and application of machine learning approaches to reveal the significance of the underlying patterns, VDR binding and transcriptional activity. Whilst the VDR was not included in the ENCODE project, judicious choice of a cell line model for these studies, most likely a Tier 1 cell line from ENCODE, will enable leverage of a considerable volume of cistromic and epigenomic data to be combined with de novo VDR ChIP-Seq data. In this manner the question of how $\mathrm{TGF}^{\circledR}$ and/or WNT signaling interacts directly or indirectly with VDR binding can be addressed relatively easily.

Another major knowledge gap in VDR understanding concerns the spatial relationships between VDR binding and the control of transcription. It is clear that chromatin looping processes can transiently bring distal regulatory regions into physical proximity to the proximal regions of a gene and lead to dynamic gene expression (Saramaki et al., 2009). To transition from examination of looping of this process at a single locus using established binding sites to the genome wide investigation is technically and statistically very challenging. Again, ENCODE analyses may be useful here, as Chromatin Interaction Analysis by Paired-End Tag Sequencing (ChIA-PET) data are available for specific cell lines; for example using RNA-PolII in K562 cells and therefore VDR ChIP-Seq in these cells would again be able to leverage this data to begin to understand how the VDR distributes and loops across the genome.

\section{WHAT IS THE ROLE OF GENETIC VARIATION IN DETERMINING HOW AND WHERE THE VDR BINDS?}

Genetic variation exists throughout the genome and by definition is predominately in non-RNA coding regions. This realization has been the catalyst for examining how genetic variation impacts transcription factor binding and activity. Perhaps the most comprehensive integration of these concepts has been the development of the RegulomeDB tool (Boyle et al., 2012) which considers the impact of genetic variation on the function of all transcription factors analyzed by ENCODE. To date this question has not been seriously considered in terms of the VDR. A major hurdle to addressing this question is very large potential for Type 1 error owing to the large-scale data sets that need to be integrated, namely; all SNPs and those in linkeage disequilibrium that are significantly associated with disease in replicated studies and all binding sites for a given transcription factor against the backdrop of the number of SNPs for a given trait, the platform used for identification and the total number of SNPs in the human genome. In the context of the VDR specifically, this challenge is compounded by the fact that the majority of VDR binding sites through the genome do not contain a canonical DR3 type binding element and therefore a critical question will remain around what protein is the VDR interacting with in the genomic context and how is this influenced by genetic variation. This challenge is clearly intertwined with developing a comprehensive knowledge of how the VDR binds to the genome.

\section{WHAT IS THE COMPLETE VDR TRANSCRIPTOME AND HOW DOES IT DIFFER BY TISSUE AND BY DISEASE?}

Surprisingly, no RNA-Seq data are yet available for the VDR. Therefore to capture all RNA regulated by the VDR will require RNA-Seq approaches applied to libraries that capture short and 
long RNA species. The ENCODE consortium have undertaken over 400 RNA-Seq experiments focused on different RNA species in multiple cell models, and this makes a compelling case for exploiting these data, especially in Tier 1 or Tier 2 cell lines. For example undertaking VDR ChIP-Seq and a limited number of RNA-Seq approaches in K562 cells has the potential to leverage a remarkable volume of data. Predictions from such integrative analyses could then be tested in other ENCODE resources, in RNA-Seq from multiple tissues in normal healthy donors, through the GTEx consortium, or through the vast numbers of microarrays that are publically available. For example, in the case of $\mathrm{K} 562$, which is a CML cell line, there are many large-scale microarray analyses of patients with CML to examine how the VDR transcriptome relates to disease state and drug response. A parallel outcome of investigating VDR function will be to address the role it plays in regulating splice variation as suggested by the interactions with proteins such as SNW1.

\section{HOW WILL THIS KNOWLEDGE BE EXPLOITED IN PERSONALIZED MEASURES OF VDR SYSTEM IN HEALTH AND DISEASE?}

Many aspects of the relationships identified above can be interpreted by serum borne measurements, which are highly attractive owing to their ease of measurement. Serum levels of the prohormone, 25( $\mathrm{OH})$ vitamin $\mathrm{D} 3$, are strongly correlated with the generation of the active hormone $1 \alpha, 25(\mathrm{OH})_{2} \mathrm{D}_{3}$ and VDR function. For example, reduced serum levels of $25(\mathrm{OH})$ vitamin $\mathrm{D} 3$ levels are associated with increased risk of either cancer initiation and/or progression (Drake et al., 2010; Shanafelt et al., 2011). Therefore the serum level of $25(\mathrm{OH})$ vitamin D3can yield the "potential" of the VDR system to signal (Brader et al., 2014). This potential is impacted by the various cellular mechanisms outlined above. Of these, genetic variation that impacts VDR binding can obviously be measured in any cell in the body. The total transcriptome can be challenging to measure but perhaps small non-coding RNA represent a highly attractive marker of activity. Remarkably, miRNA are readily secreted into serum where they remain stable (El-Hefnawy et al., 2004; Goyal et al., 2006; Taylor and Gercel-Taylor, 2008; Valadi et al., 2007) and can be reliably extracted and measured (Chen et al., 2008; Liu et al., 2008; Mitchell et al., 2008; Rabinowits et al., 2009). Using serumborne molecules as prognostic markers is highly attractive for several reasons. First, they can overcome the limitations of inaccurate sampling for example in the case of the presence of cancer within a tumor biopsy. Second, they can encapsulate the effects of heterotypic cell interactions, again, for example within the tumor microenvironment. Third, they form a non-invasive test procedure. From a biostatistical perspective, given there are fewer miRNA than protein coding mRNA, genome-wide coverage is more readily achieved and avoids the statistical penalties typically associated mRNA genome wide testing (Lussier et al., 2012).

This raises the very exciting possibility that generating integrated models of VDR binding, the impact of genetic variation, the tissue specific differences in the transcriptome and identifying miRNA contained within transcriptional circuits offers the opportunity of exploiting their serum expression levels of $25(\mathrm{OH})$ vitamin D3, genetic variation and miRNA expression will be able to be exploited to predict accurately the capacity of VDR function.

\section{ACKNOWLEDGMENTS}

Moray J. Campbell acknowledges support in part from National Institute of Health grants [R01 CA095367-06 and 2R01-CA095045-06] and the NCI Cancer Center Support Grant to the Roswell Park Cancer Institute [CA016056].

\section{REFERENCES}

Akutsu, N., Lin, R., Bastien, Y., Bestawros, A., Enepekides, D. J., Black, M. J., et al. (2001). Regulation of gene Expression by 1alpha,25-dihydroxyvitamin D3 and Its analog EB1089 under growth-inhibitory conditions in squamous carcinoma Cells. Mol. Endocrinol. 15, 1127-1139. doi: 10.1210/mend.15.7.0655

Alvarez-Diaz, S., Valle, N., Ferrer-Mayorga, G., Lombardia, L., Herrera, M., Dominguez, O., et al. (2012). MicroRNA-22 is induced by vitamin D and contributes to its antiproliferative, antimigratory and gene regulatory effects in colon cancer cells. Hum. Mol. Genet. 21, 2157-2165. doi: 10.1093/hmg/ dds031

Amir, S., Ma, A. H., Shi, X. B., Xue, L., Kung, H. J., and Devere White, R. W. (2013). Oncomir miR-125b suppresses p14(ARF) to modulate p53-dependent and p53-independent apoptosis in prostate cancer. PLoS ONE 8:e61064. doi: 10.1371/journal.pone.0061064

Anderson, P. H., O'Loughlin, P. D., May, B. K., and Morris, H. A. (2003). Quantification of mRNA for the vitamin D metabolizing enzymes CYP27B1 and CYP24 and vitamin D receptor in kidney using real-time reverse transcriptase- polymerase chain reaction. J. Mol. Endocrinol. 31, 123-132. doi: 10.1677/jme.0.0310123

Aubol, B. E., Jamros, M. A., McGlone, M. L., and Adams, J. A. (2013). Splicing kinase SRPK1 conforms to the landscape of its SR protein substrate. Biochemistry 52, 7595-7605. doi: 10.1021/bi4010864

Baeke, F., Korf, H., Overbergh, L., Verstuyf, A., Thorrez, L., Van Lommel, L., et al. (2011). The vitamin D analog, TX527, promotes a human CD4+CD25highCD127low regulatory $\mathrm{T}$ cell profile and induces a migratory signature specific for homing to sites of inflammation. J. Immunol. 186, 132-142. doi: 10.4049/jimmunol.1000695

Baker, A. R., McDonnell, D. P., Hughes, M., Crisp, T. M., Mangelsdorf, D. J., Haussler, M. R., et al. (1988). Cloning and expression of full-length cDNA encoding human vitamin D receptor. Proc. Natl. Acad. Sci. U.S.A. 85, 3294-3298. doi: 10.1073/pnas.85.10.3294

Barrett, T., Suzek, T. O., Troup, D. B., Wilhite, S. E., Ngau, W. C., Ledoux, P., et al. (2005). NCBI GEO: mining millions of expression profiles-database and tools. Nucleic Acids Res. 33, D562-D566. doi: 10.1093/nar/gki022

Barrett, T., Wilhite, S. E., Ledoux, P., Evangelista, C., Kim, I. F., Tomashevsky, M., et al. (2013). NCBI GEO: archive for functional genomics data sets-update. Nucleic Acids Res. 41, D991-D995. doi: 10.1093/nar/gks1193

Baudino, T. A., Kraichely, D. M., Jefcoat, S. C. Jr., Winchester, S. K., Partridge, N. C., and MacDonald, P. N. (1998). Isolation and characterization of a novel coactivator protein, NCoA-62, involved in vitamin D-mediated transcription. J. Biol. Chem. 273, 16434-16441. doi: 10.1074/jbc.273.26.16434

Birney, E. (2012). The making of ENCODE: lessons for big-data projects. Nature 489, 49-51. doi: 10.1038/489049a

Birney, E., Stamatoyannopoulos, J. A., Dutta, A., Guigo, R., Gingeras, T. R., Margulies, E. H., et al. (2007). Identification and analysis of functional elements in $1 \%$ of the human genome by the ENCODE pilot project. Nature 447, 799-816. doi: 10.1038/nature05874

Bosse, Y., Maghni, K., and Hudson, T. J. (2007). lalpha,25-dihydroxy-vitamin D3 stimulation of bronchial smooth muscle cells induces autocrine, contractility, and remodeling processes. Physiol. Genomics 29, 161-168. doi: 10.1152/physiolgenomics.00134.2006

Boyle, A. P., Hong, E. L., Hariharan, M., Cheng, Y., Schaub, M. A., Kasowski, M., et al. (2012). Annotation of functional variation in personal genomes using RegulomeDB. Genome Res. 22, 1790-1797. doi: 10.1101/gr.137323.112

Brader, L., Rejnmark, L., Carlberg, C., Schwab, U., Kolehmainen, M., Rosqvist, F., et al. (2014). Effects of a healthy Nordic diet on plasma 25-hydroxyvitamin D concentration in subjects with metabolic syndrome: a randomized, placebocontrolled trial (SYSDIET). Eur. J. Nutr. doi: 10.1007/s00394-014-0674-3. [Epub ahead of print].

Brazma, A., Hingamp, P., Quackenbush, J., Sherlock, G., Spellman, P., Stoeckert, C., et al. (2001). Minimum information about a microarray experiment 
(MIAME)-toward standards for microarray data. Nat. Genet. 29, 365-371. doi: 10.1038/ng1201-365

Campbell, M. J., Elstner, E., Holden, S., Uskokovic, M., and Koeffler, H. P. (1997). Inhibition of proliferation of prostate cancer cells by a 19-nor-hexafluoride vitamin D3 analogue involves the induction of p21waf1, p27kip1 and E-cadherin. J. Mol. Endocrinol. 19, 15-27. doi: 10.1677/jme.0.0190015

Carlberg, C., and Campbell, M. J. (2013). Vitamin D receptor signaling mechanisms: integrated actions of a well-defined transcription factor. Steroids 78 , 127-136. doi: 10.1016/j.steroids.2012.10.019

Carroll, J. S., Meyer, C. A., Song, J., Li, W., Geistlinger, T. R., Eeckhoute, J., et al. (2006). Genome-wide analysis of estrogen receptor binding sites. Nat. Genet. 38, 1289-1297. doi: 10.1038/ng1901

Cenciarelli, C., De Santa, F., Puri, P. L., Mattei, E., Ricci, L., Bucci, F., et al. (1999) Critical role played by cyclin D3 in the MyoD-mediated arrest of cell cycle during myoblast differentiation. Mol. Cell. Biol. 19, 5203-5217.

Chen, X., Ba, Y., Ma, L., Cai, X., Yin, Y., Wang, K., et al. (2008). Characterization of microRNAs in serum: a novel class of biomarkers for diagnosis of cancer and other diseases. Cell Res. 18, 997-1006. doi: 10.1038/cr.2008.282

Colston, K., Colston, M. J., Fieldsteel, A. H., and Feldman, D. (1982). 1,25dihydroxyvitamin D3 receptors in human epithelial cancer cell lines. Cancer Res. 42, 856-859.

Colston, K. W., Berger, U., and Coombes, R. C. (1989). Possible role for vitamin D in controlling breast cancer cell proliferation. Lancet 1, 188-191.

Consortium, E. P., Birney, E., Stamatoyannopoulos, J. A., Dutta, A., Guigo, R., Gingeras, T. R., et al. (2007). Identification and analysis of functional elements in $1 \%$ of the human genome by the ENCODE pilot project. Nature 447 , 799-816. doi: 10.1038/nature05874

Consortium, G. T. (2013). The Genotype-Tissue Expression (GTEx) project. Nat. Genet. 45, 580-585. doi: 10.1038/ng.2653

Costa, J. L., Eijk, P. P., van de Wiel, M. A., ten Berge, D., Schmitt, F., Narvaez, C. J., et al. (2009). Anti-proliferative action of vitamin D in MCF7 is still active after siRNA-VDR knock-down. BMC Genomics 10:499. doi: 10.1186/1471-216410-499

Cui, M., Klopot, A., Jiang, Y., and Fleet, J. C. (2009). The effect of differentiation on 1,25 dihydroxyvitamin D-mediated gene expression in the enterocyte-like cell line, Caco-2. J. Cell. Physiol. 218, 113-121. doi: 10.1002/jcp.21574

Despouy, G., Bastie, J. N., Deshaies, S., Balitrand, N., Mazharian, A., Rochette-Egly, C., et al. (2003). Cyclin D3 is a cofactor of retinoic acid receptors, modulating their activity in the presence of cellular retinoic acid-binding protein II. J. Biol. Chem. 278, 6355-6362. doi: 10.1074/jbc.M210697200

Ding, N., Yu, R. T., Subramaniam, N., Sherman, M. H., Wilson, C., Rao, R., et al. (2013). A vitamin D receptor/SMAD genomic circuit gates hepatic fibrotic response. Cell 153, 601-613. doi: 10.1016/j.cell.2013.03.028

Do, J. H., and Choi, D. K. (2006). Normalization of microarray data: single-labeled and dual-labeled arrays. Mol. Cells 22, 254-261.

Dobrzynski, M., and Bruggeman, F. J. (2009). Elongation dynamics shape bursty transcription and translation. Proc. Natl. Acad. Sci. U.S.A. 106, 2583-2588. doi 10.1073/pnas.0803507106

Doig, C. L., Singh, P. K., Dhiman, V. K., Thorne, J. L., Battaglia, S., Sobolewski, M., et al. (2013). Recruitment of NCOR1 to VDR target genes is enhanced in prostate cancer cells and associates with altered DNA methylation patterns. Carcinogenesis 34, 248-256. doi: 10.1093/carcin/bgs331

Doolittle, W. F. (2013). Is junk DNA bunk? A critique of ENCODE. Proc. Natl. Acad. Sci. U.S.A. 110, 5294-5300. doi: 10.1073/pnas.1221376110

Drake, M. T., Maurer, M. J., Link, B. K., Habermann, T. M., Ansell, S. M., Micallef, I. N., et al. (2010). Vitamin D insufficiency and prognosis in nonHodgkin's lymphoma. J. Clin. Oncol. 28, 4191-4198. doi: 10.1200/JCO.2010. 28.6674

Dunlop, T. W., Vaisanen, S., Frank, C., and Carlberg, C. (2004). The genes of the coactivator TIF2 and the corepressor SMRT are primary lalpha,25(OH)2D3 targets. J. Steroid Biochem. Mol. Biol. 89-90, 257-260. doi: 10.1016/j.jsbmb.2004.03.079

Dwivedi, P. P., Omdahl, J. L., Kola, I., Hume, D. A., and May, B. K. (2000). Regulation of rat cytochrome P450C24 (CYP24) gene expression. Evidence for functional cooperation of Ras-activated Ets transcription factors with the vitamin D receptor in 1,25-dihydroxyvitamin $\mathrm{D}(3)$-mediated induction. J. Biol. Chem. 275, 47-55. doi: 10.1074/jbc.275.1.47

Eelen, G., Verlinden, L., Van Camp, M., Mathieu, C., Carmeliet, G., Bouillon, R., et al. (2004). Microarray analysis of lalpha,25-dihydroxyvitamin D3-treated
MC3T3-E1 cells. J. Steroid Biochem. Mol. Biol. 89-90, 405-407. doi: 10.1016/j.jsbmb.2004.03.008

El-Hefnawy, T., Raja, S., Kelly, L., Bigbee, W. L., Kirkwood, J. M., Luketich, J. D., et al. (2004). Characterization of amplifiable, circulating RNA in plasma and its potential as a tool for cancer diagnostics. Clin. Chem. 50, 564-573. doi: 10.1373/clinchem.2003.028506

Ellison, T. I., Smith, M. K., Gilliam, A. C., and MacDonald, P. N. (2008). Inactivation of the vitamin $\mathrm{D}$ receptor enhances susceptibility of murine skin to UV-induced tumorigenesis. J. Invest. Dermatol. 128, 2508-2517. doi: 10.1038/jid.2008.131

Elstner, E., Campbell, M. J., Munker, R., Shintaku, P., Binderup, L., Heber, D., et al. (1999). Novel 20-epi-vitamin D3 analog combined with 9-cis-retinoic acid markedly inhibits colony growth of prostate cancer cells. Prostate 40, 141-149. doi: 10.1002/(SICI) 1097-0045(19990801)40:3\%3C141::AIDPROS1\%3E3.0.CO;2-C

Engreitz, J. M., Chen, R., Morgan, A. A., Dudley, J. T., Mallelwar, R., and Butte, A. J. (2011). ProfileChaser: searching microarray repositories based on genomewide patterns of differential expression. Bioinformatics 27, 3317-3318. doi: 10.1093/bioinformatics/btr548

Gatfield, D., Le Martelot, G., Vejnar, C. E., Gerlach, D., Schaad, O., Fleury-Olela, F., et al. (2009). Integration of microRNA miR-122 in hepatic circadian gene expression. Genes Dev. 23, 1313-1326. doi: 10.1101/gad.1781009

Gkika, D., Mahieu, F., Nilius, B., Hoenderop, J. G., and Bindels, R. J. (2004). 80K$\mathrm{H}$ as a new $\mathrm{Ca} 2+$ sensor regulating the activity of the epithelial $\mathrm{Ca} 2+$ channel transient receptor potential cation channel V5 (TRPV5). J. Biol. Chem. 279, 26351-26357. doi: 10.1074/jbc.M403801200

Goldberg, A. D., Allis, C. D., and Bernstein, E. (2007). Epigenetics: a landscape takes shape. Cell 128, 635-638. doi: 10.1016/j.cell.2007.02.006

Goyal, A., Delves, G. H., Chopra, M., Lwaleed, B. A., and Cooper, A. J. (2006) Prostate cells exposed to lycopene in vitro liberate lycopene-enriched exosomes. BJU Int. 98, 907-911. doi: 10.1111/j.1464-410X.2006.06434.x

Guan, H., Liu, C., Chen, Z., Wang, L., Li, C., Zhao, J., et al. (2013). 1,25 Dihydroxyvitamin D3 up-regulates expression of hsa-let-7a-2 through the interaction of VDR/VDRE in human lung cancer A549 cells. Gene 522, 142-146. doi: 10.1016/j.gene.2013.03.065

Gynther, P., Toropainen, S., Matilainen, J. M., Seuter, S., Carlberg, C., and Vaisanen, S. (2011). Mechanism of 1alpha,25-dihydroxyvitamin D(3)dependent repression of interleukin-12B. Biochim. Biophys. Acta 1813, 810-818. doi: 10.1016/j.bbamcr.2011.01.037

Hayes, G. M., Carrigan, P. E., Beck, A. M., and Miller, L. J. (2006). Targeting the RNA splicing machinery as a novel treatment strategy for pancreatic carcinoma. Cancer Res. 66, 3819-3827. doi: 10.1158/0008-5472.CAN-05-4065

Heikkinen, S., Vaisanen, S., Pehkonen, P., Seuter, S., Benes, V., and Carlberg, C. (2011). Nuclear hormone lalpha,25-dihydroxyvitamin D3 elicits a genomewide shift in the locations of VDR chromatin occupancy. Nucleic Acids Res. 39, 9181-9193. doi: 10.1093/nar/gkr654

Hengst, L., and Reed, S. I. (1996). Translational control of p27Kip1 accumulation during the cell cycle. Science 271, 1861-1864. doi: 10.1126/science.271.5257.1861

Hsieh, J. C., Sisk, J. M., Jurutka, P. W., Haussler, C. A., Slater, S. A., Haussler, M. R., et al. (2003). Physical and functional interaction between the vitamin D receptor and hairless corepressor, two proteins required for hair cycling. J. Biol. Chem. 278, 38665-38674. doi: 10.1074/jbc.M304886200

Huang, Y. C., Chen, J. Y., and Hung, W. C. (2004). Vitamin D(3) receptor/Sp1 complex is required for the induction of $\mathrm{p} 27$ (Kip1) expression by vitamin $\mathrm{D}(3)$. Oncogene doi: 10.1038/sj.onc.1207621

Iosue, I., Quaranta, R., Masciarelli, S., Fontemaggi, G., Batassa, E. M., Bertolami, C., et al. (2013). Argonaute 2 sustains the gene expression program driving human monocytic differentiation of acute myeloid leukemia cells. Cell Death Dis. 4, e926. doi: 10.1038/cddis.2013.452

Ito, I., Waku, T., Aoki, M., Abe, R., Nagai, Y., Watanabe, T., et al. (2013). A nonclassical vitamin D receptor pathway suppresses renal fibrosis. J. Clin. Invest. 123, 4579-4594. doi: 10.1172/JCI67804

Ivanovska, I., Ball, A. S., Diaz, R. L., Magnus, J. F., Kibukawa, M., Schelter, J. M., et al. (2008). MicroRNAs in the miR-106b family regulate p21/CDKN1A and promote cell cycle progression. Mol. Cell. Biol. 28, 2167-2174. doi: 10.1128/MCB.01977-07

Jenuwein, T., and Allis, C. D. (2001). Translating the histone code. Science 293, 1074-1080. doi: 10.1126/science.1063127 
Jiang, F., Li, P., Fornace, A. J. Jr., Nicosia, S. V., and Bai, W. (2003). G2/M arrest by 1,25-dihydroxyvitamin D3 in ovarian cancer cells mediated through the induction of GADD45 via an exonic enhancer. J. Biol. Chem. 278, 48030-48040. doi: 10.1074/jbc.M308430200

Jiang, Y. J., and Bikle, D. D. (2014). LncRNA: a new player in 1alpha, 25(OH)2 vitamin D3 /VDR protection against skin cancer formation. Exp. Dermatol. 23, 147-150. doi: 10.1111/exd.12341

Kangaspeska, S., Stride, B., Metivier, R., Polycarpou-Schwarz, M., Ibberson, D., Carmouche, R. P., et al. (2008). Transient cyclical methylation of promoter DNA. Nature 452, 112-115. doi: 10.1038/nature06640

Kapranov, P., and St Laurent, G. (2012). Dark matter RNA: existence, function, and controversy. Front. Genet. 3:60. doi: 10.3389/fgene.2012.00060

Katoh, M., and Katoh, M. (2007). WNT signaling pathway and stem cell signaling network. Clin. Cancer Res. 13, 4042-4045. doi: 10.1158/1078-0432.CCR06-2316

Khanim, F. L., Gommersall, L. M., Wood, V. H., Smith, K. L., Montalvo, L., O’Neill, L. P., et al. (2004). Altered SMRT levels disrupt vitamin D3 receptor signalling in prostate cancer cells. Oncogene 23, 6712-6725. doi: 10.1038/sj.onc. 1207772

Kim, J. Y., Son, Y. L., and Lee, Y. C. (2009). Involvement of SMRT Corepressor in Transcriptional Repression by the Vitamin D Receptor. Mol. Endocrinol. 23, 251-264. doi: 10.1210/me.2008-0426

Kim, S., Shevde, N. K., and Pike, J. W. (2005). 1,25-Dihydroxyvitamin D3 stimulates cyclic vitamin D receptor/retinoid X receptor DNA-binding, co-activator recruitment, and histone acetylation in intact osteoblasts. J. Bone Miner. Res. 20, 305-317. doi: 10.1359/JBMR.041112

Koike, M., Elstner, E., Campbell, M. J., Asou, H., Uskokovic, M., Tsuruoka, N., et al. (1997). 19-nor-hexafluoride analogue of vitamin D3: a novel class of potent inhibitors of proliferation of human breast cell lines. Cancer Res. 57, 4545-4550.

Kommagani, R., Caserta, T. M., and Kadakia, M. P. (2006). Identification of vitamin D receptor as a target of p63. Oncogene 25, 3745-3751. doi: 10.1038/sj.onc. 1209412

Kovalenko, P. L., Zhang, Z., Yu, J. G., Li, Y., Clinton, S. K., and Fleet, J. C. (2011). Dietary vitamin D and vitamin D receptor level modulate epithelial cell proliferation and apoptosis in the prostate. Cancer Prev. Res. (Phila.) 4, 1617-1625. doi: 10.1158/1940-6207.CAPR-11-0035

Lai, Y., Zhang, F., Nayak, T. K., Modarres, R., Lee, N. H., and McCaffrey, T. A. (2014). Concordant integrative gene set enrichment analysis of multiple largescale two-sample expression data sets. BMC Genomics 15(Suppl. 1), S6. doi: 10.1186/1471-2164-15-S1-S6

Lambert, J. R., Kelly, J. A., Shim, M., Huffer, W. E., Nordeen, S. K., Baek, S. J., et al. (2006). Prostate derived factor in human prostate cancer cells: gene induction by vitamin D via a p53-dependent mechanism and inhibition of prostate cancer cell growth. J. Cell. Physiol. 208, 566-574. doi: 10.1002/jcp.20692

Lazaro, J. B., Bailey, P. J., and Lassar, A. B. (2002). Cyclin D-cdk4 activity modulates the subnuclear localization and interaction of MEF2 with SRC-family coactivators during skeletal muscle differentiation. Genes Dev. 16, 1792-1805. doi: 10.1101/gad.U-9988R

Le May, N., Mota-Fernandes, D., Velez-Cruz, R., Iltis, I., Biard, D., and Egly, J. M. (2010). NER factors are recruited to active promoters and facilitate chromatin modification for transcription in the absence of exogenous genotoxic attack. Mol. Cell 38, 54-66. doi: 10.1016/j.molcel.2010.03.004

Leong, G. M., Subramaniam, N., Figueroa, J., Flanagan, J. L., Hayman, M. J., Eisman, J. A., et al. (2001). Ski-interacting protein interacts with Smad proteins to augment transforming growth factor-beta-dependent transcription. J. Biol. Chem. 276, 18243-18248. doi: 10.1074/jbc.M010815200

Li, P., Li, C., Zhao, X., Zhang, X., Nicosia, S. V., and Bai, W. (2004). p27(Kip1) stabilization and $\mathrm{G}(1)$ arrest by 1,25-dihydroxyvitamin $\mathrm{D}(3)$ in ovarian cancer cells mediated through down-regulation of cyclin E/cyclin-dependent kinase 2 and Skp1-Cullin-F-box protein/Skp2 ubiquitin ligase. J. Biol. Chem. 279, 25260-25267. doi: 10.1074/jbc.M311052200

Lin, R., Nagai, Y., Sladek, R., Bastien, Y., Ho, J., Petrecca, K., et al. (2002). Expression profiling in squamous carcinoma cells reveals pleiotropic effects of vitamin D3 analog EB1089 signaling on cell proliferation, differentiation, and immune system regulation. Mol. Endocrinol. 16, 1243-1256. doi: 10.1210/mend.16.6.0874

Ling, H., Fabbri, M., and Calin, G. A. (2013). MicroRNAs and other non-coding RNAs as targets for anticancer drug development. Nat. Rev. Drug Discov. 12, 847-865. doi: 10.1038/nrd4140

Lisse, T. S., Liu, T., Irmler, M., Beckers, J., Chen, H., Adams, J. S., et al. (2011). Gene targeting by the vitamin D response element binding protein reveals a role for vitamin $\mathrm{D}$ in osteoblast mTOR signaling. FASEB J. 25, 937-947. doi: 10.1096/fj.10-172577

Liu, C. G., Calin, G. A., Volinia, S., and Croce, C. M. (2008). MicroRNA expression profiling using microarrays. Nat. Protoc. 3, 563-578. doi: 10.1038/nprot.2008.14

Liu, M., Lee, M. H., Cohen, M., Bommakanti, M., and Freedman, L. P. (1996). Transcriptional activation of the Cdk inhibitor p21 by vitamin D3 leads to the induced differentiation of the myelomonocytic cell line U937. Genes Dev. 10, 142-153. doi: 10.1101/gad.10.2.142

Lupien, M., Eeckhoute, J., Meyer, C. A., Wang, Q., Zhang, Y., Li, W., et al. (2008). FoxA1 translates epigenetic signatures into enhancer-driven lineage-specific transcription. Cell 132, 958-970. doi: 10.1016/j.cell.2008.01.018

Lussier, Y. A., Stadler, W. M., and Chen, J. L. (2012). Advantages of genomic complexity: bioinformatics opportunities in microRNA cancer signatures. J. Am. Med. Inform. Assoc. 19, 156-160. doi: 10.1136/amiajnl-2011-000419

Mahajan, M. A., and Samuels, H. H. (2000). A new family of nuclear receptor coregulators that integrate nuclear receptor signaling through CREB-binding protein. Mol. Cell. Biol. 20, 5048-5063. doi: 10.1128/MCB.20.14.5048-5063.2000

Maher, B. (2012). ENCODE: The human encyclopaedia. Nature 489, 46-48. doi: $10.1038 / 489046 a$

Malinen, M., Saramaki, A., Ropponen, A., Degenhardt, T., Vaisanen, S., and Carlberg, C. (2008). Distinct HDACs regulate the transcriptional response of human cyclin-dependent kinase inhibitor genes to Trichostatin A and 1alpha,25-dihydroxyvitamin D3. Nucleic Acids Res. 36, 121-132. doi: 10.1093/nar/gkm913

Mangan, S., and Alon, U. (2003). Structure and function of the feed-forward loop network motif. Proc. Natl. Acad. Sci. U.S.A. 100, 11980-11985. doi: 10.1073/pnas.2133841100

Mangan, S., Itzkovitz, S., Zaslaver, A., and Alon, U. (2006). The incoherent feedforward loop accelerates the response-time of the gal system of Escherichia coli. J. Mol. Biol. 356, 1073-1081. doi: 10.1016/j.jmb.2005.12.003

Marinelli, R. J., Montgomery, K., Liu, C. L., Shah, N. H., Prapong, W., Nitzberg, M., et al. (2008). The stanford tissue microarray database. Nucleic Acids Res. 36, D871-D877. doi: 10.1093/nar/gkm861

Martinez-Climent, J. A., Fontan, L., Fresquet, V., Robles, E., Ortiz, M., and Rubio, A. (2010). Integrative oncogenomic analysis of microarray data in hematologic malignancies. Methods Mol. Biol. 576, 231-277. doi: 10.1007/978-1-59745545-9_13

Maruyama, R., Aoki, F., Toyota, M., Sasaki, Y., Akashi, H., Mita, H., et al. (2006). Comparative genome analysis identifies the vitamin $\mathrm{D}$ receptor gene as a direct target of p53-mediated transcriptional activation. Cancer Res. 66, 4574-4583. doi: 10.1158/0008-5472.CAN-05-2562

Metivier, R., Gallais, R., Tiffoche, C., Le Peron, C., Jurkowska, R. Z., Carmouche, R. P., et al. (2008). Cyclical DNA methylation of a transcriptionally active promoter. Nature 452, 45-50. doi: 10.1038/nature06544

Metivier, R., Penot, G., Hubner, M. R., Reid, G., Brand, H., Kos, M., et al. (2003). Estrogen receptor-alpha directs ordered, cyclical, and combinatorial recruitment of cofactors on a natural target promoter. Cell 115, 751-763. doi: 10.1016/S0092-8674(03)00934-6

Meyer, M. B., Goetsch, P. D., and Pike, J. W. (2012). VDR/RXR and TCF4/betacatenin cistromes in colonic cells of colorectal tumor origin: impact on c-FOS and c-MYC gene expression. Mol. Endocrinol. 26, 37-51. doi: 10.1210/me.20 11-1109

Meyer, M. B., Watanuki, M., Kim, S., Shevde, N. K., and Pike, J. W. (2006). The human transient receptor potential vanilloid type 6 distal promoter contains multiple vitamin D receptor binding sites that mediate activation by 1,25 dihydroxyvitamin D3 in intestinal cells. Mol. Endocrinol. 20, 1447-1461. doi: 10.1210/me.2006-0031

Mitchell, P. S., Parkin, R. K., Kroh, E. M., Fritz, B. R., Wyman, S. K., PogosovaAgadjanyan, E. L., et al. (2008). Circulating microRNAs as stable blood-based markers for cancer detection. Proc. Natl. Acad. Sci. U.S.A. 105, 10513-10518. doi: 10.1073/pnas.0804549105

Mohn, F., and Schubeler, D. (2009). Genetics and epigenetics: stability and plasticity during cellular differentiation. Trends Genet. 25, 129-136. doi: 10.1016/j.tig.2008.12.005

Mohri, T., Nakajima, M., Takagi, S., Komagata, S., and Yokoi, T. (2009). MicroRNA regulates human vitamin D receptor. Int. J. Cancer 125, 1328-1333. doi: 10.1002/ijc. 24459

Novershtern, N., Subramanian, A., Lawton, L. N., Mak, R. H., Haining, W. N., McConkey, M. E., et al. (2011). Densely interconnected transcriptional 
circuits control cell states in human hematopoiesis. Cell 144, 296-309. doi: 10.1016/j.cell.2011.01.004

Orlov, I., Rochel, N., Moras, D., and Klaholz, B. P. (2012). Structure of the full human RXR/VDR nuclear receptor heterodimer complex with its DR3 target DNA. EMBO J. 31, 291-300. doi: 10.1038/emboj.2011.445

Osoegawa, K., Tateno, M., Woon, P. Y., Frengen, E., Mammoser, A. G., Catanese, J. J., et al. (2000). Bacterial artificial chromosome libraries for mouse sequencing and functional analysis. Genome Res. 10, 116-128.

Padi, S. K., Zhang, Q., Rustum, Y. M., Morrison, C., and Guo, B. (2013). MicroRNA-627 mediates the epigenetic mechanisms of vitamin D to suppress proliferation of human colorectal cancer cells and growth of xenograft tumors in mice. Gastroenterology 145, 437-446. doi: 10.1053/j.gastro.2013. 04.012

Pálmer, H. G., González-Sancho, J. M., Espada, J., Berciano, M. T., Puig, I., Baulida, J., et al. (2001). Vitamin D(3) promotes the differentiation of colon carcinoma cells by the induction of E-cadherin and the inhibition of beta-catenin signaling. J. Cell. Biol. 154, 369-387. doi: 10.1083/jcb.200102028

Pálmer, H. G., Sánchez-Carbayo, M., Ordóñez-Morán, P., Larriba, M. J., CordónCardó, C, and Muñoz, A. (2003). Genetic signatures of differentiation induced by 1alpha,25-dihydroxyvitamin D3 in human colon cancer cells. Cancer Res. 63 , 7799-7806.

Parkinson, H., Kapushesky, M., Shojatalab, M., Abeygunawardena, N., Coulson, R., Farne, A., et al. (2007). ArrayExpress-a public database of microarray experiments and gene expression profiles. Nucleic Acids Res. 35, D747-D750. doi: 10.1093/nar/gkl995

Peehl, D. M., Skowronski, R. J., Leung, G. K., Wong, S. T., Stamey, T. A., and Feldman, D. (1994). Antiproliferative effects of 1,25-dihydroxyvitamin D3 on primary cultures of human prostatic cells. Cancer Res. 54, 805-810.

Peleg, S., and Nguyen, C. V. (2010). The importance of nuclear import in protection of the vitamin D receptor from polyubiquitination and proteasome-mediated degradation. J. Cell. Biochem. 110, 926-934. doi: 10.1002/jcb.22606

Pereira, F., Barbachano, A., Silva, J., Bonilla, F., Campbell, M. J., Munoz, A., et al. (2011). KDM6B/JMJD3 histone demethylase is induced by vitamin D and modulates its effects in colon cancer cells. Hum. Mol. Genet. 20, 4655-4665. doi: $10.1093 / \mathrm{hmg} / \mathrm{ddr} 399$

Pihlajamaa, P., Sahu, B., Lyly, L., Aittomaki, V., Hautaniemi, S., and Janne, O. A. (2014). Tissue-specific pioneer factors associate with androgen receptor cistromes and transcription programs. EMBO J. 33, 312-326. doi: 10.1002/embj.201385895

Pike, J. W., Gooze, L. L., and Haussler, M. R. (1980). Biochemical evidence for 1,25-dihydroxyvitamin $\mathrm{D}$ receptor macromolecules in parathyroid, pancreatic, pituitary, and placental tissues. Life Sci. 26, 407-414. doi: 10.1016/00243205(80)90158-7

Polly, P., Herdick, M., Moehren, U., Baniahmad, A., Heinzel, T., and Carlberg, C. (2000). VDR-Alien: a novel, DNA-selective vitamin D(3) receptor-corepressor partnership. FASEB J. 14, 1455-1463. doi: 10.1096/fj.14.10.1455

Quack, M., and Carlberg, C. (2000). The impact of functional vitamin D(3) receptor conformations on DNA-dependent vitamin D(3) signaling. Mol. Pharmacol. 57, 375-384.

Rabinowits, G., Gercel-Taylor, C., Day, J. M., Taylor, D. D., and Kloecker, G. H. (2009). Exosomal microRNA: a diagnostic marker for lung cancer. Clin. Lung Cancer. 10, 42-46. doi: 10.3816/CLC.2009.n.006

Ramagopalan, S. V., Heger, A., Berlanga, A. J., Maugeri, N. J., Lincoln, M. R. Burrell, A., et al. (2010). A ChIP-seq defined genome-wide map of vitamin D receptor binding: associations with disease and evolution. Genome Res. 20, 1352-1360. doi: 10.1101/gr.107920.110

Rantala, J. K., Edgren, H., Lehtinen, L., Wolf, M., Kleivi, K., Vollan, H. K., et al. (2010). Integrative functional genomics analysis of sustained polyploidy phenotypes in breast cancer cells identifies an oncogenic profile for GINS2. Neoplasia $12,877-888$.

Rashid, S. F., Moore, J. S., Walker, E., Driver, P. M., Engel, J., Edwards, C. E., et al. (2001). Synergistic growth inhibition of prostate cancer cells by 1 alpha, 25 Dihydroxyvitamin $\mathrm{D}(3)$ and its 19 -nor-hexafluoride analogs in combination with either sodium butyrate or trichostatin A. Oncogene 20, 1860-1872. doi: 10.1038/sj.onc. 1204269

Reid, G., Hubner, M. R., Metivier, R., Brand, H., Denger, S., Manu, D., et al. (2003). Cyclic, proteasome-mediated turnover of unliganded and liganded ERalpha on responsive promoters is an integral feature of estrogen signaling. Mol. Cell 11, 695-707. doi: 10.1016/S1097-2765(03)00090-X
Ribas, J., Ni, X., Haffner, M., Wentzel, E. A., Salmasi, A. H., Chowdhury, W. H., et al. (2009). miR-21: an androgen receptor-regulated microRNA that promotes hormone-dependent and hormone-independent prostate cancer growth. Cancer Res. 69, 7165-7169. doi: 10.1158/0008-5472.CAN-09-1448

Rid, R., Wagner, M., Maier, C. J., Hundsberger, H., Hintner, H., Bauer, J. W., et al. (2013). Deciphering the calcitriol-induced transcriptomic response in keratinocytes: presentation of novel target genes. J. Mol. Endocrinol. 50, 131-149. doi: 10.1530/JME-11-0191

Rosenbloom, K. R., Sloan, C. A., Malladi, V. S., Dreszer, T. R., Learned, K., Kirkup, V. M., et al. (2013). ENCODE data in the UCSC genome browser: year 5 update. Nucleic Acids Res. 41, D56-D63. doi: 10.1093/nar/gks1172

Sahu, B., Laakso, M., Pihlajamaa, P., Ovaska, K., Sinielnikov, I., Hautaniemi, S., et al. (2013). FoxAl specifies unique androgen and glucocorticoid receptor binding events in prostate cancer cells. Cancer Res. 73, 1570-1580. doi: 10.1158/0008-5472.CAN-12-2350

Saramaki, A., Banwell, C. M., Campbell, M. J., and Carlberg, C. (2006). Regulation of the human p21(waf1/cip1) gene promoter via multiple binding sites for p53 and the vitamin D3 receptor. Nucleic Acids Res. 34, 543-554. doi: 10.1093/nar/gkj460

Saramaki, A., Diermeier, S., Kellner, R., Laitinen, H., Vaisanen, S., and Carlberg, C. (2009). Cyclical chromatin looping and transcription factor association on the regulatory regions of the p21 (CDKN1A) gene in response to lalpha,25-dihydroxyvitamin D3. J. Biol. Chem. 284, 8073-8082. doi: 10.1074/jbc.M808090200

Sarruf, D. A., Iankova, I., Abella, A., Assou, S., Miard, S., and Fajas, L. (2005). Cyclin D3 promotes adipogenesis through activation of peroxisome proliferator-activated receptor gamma. Mol. Cell Biol. 25, 9985-9995. doi: 10.1128/MCB.25.22.9985-9995.2005

Savli, H., Aalto, Y., Nagy, B., Knuutila, S., and Pakkala, S. (2002). Gene expression analysis of 1,25(OH)2D3-dependent differentiation of HL-60 cells: a cDNA array study. Br. J. Haematol. 118, 1065-1070. doi: 10.1046/j.13652141.2002.03734.x

Schwaller, J., Koeffler, H. P., Niklaus, G., Loetscher, P., Nagel, S., Fey, M. F., et al (1995). Posttranscriptional stabilization underlies p53-independent induction of p21WAF1/CIP1/SDI1 in differentiating human leukemic cells. J. Clin. Invest. 95, 973-979. doi: 10.1172/JCI117806

Scsucova, S., Palacios, D., Savignac, M., Mellstrom, B., Naranjo, J. R., and Aranda, A. (2005). The repressor DREAM acts as a transcriptional activator on Vitamin D and retinoic acid response elements. Nucleic Acids Res. 33, 2269-2279. doi: 10.1093/nar/gki503

Seo, Y. K., Chung, Y. T., Kim, S., Echchgadda, I., Song, C. S., and Chatterjee, B. (2007). Xenobiotic- and vitamin D-responsive induction of the steroid/bile acid-sulfotransferase Sult2A1 in young and old mice: the role of a gene enhancer in the liver chromatin. Gene 386, 218-223. doi: 10.1016/j.gene.2006. 10.006

Serandour, A. A., Avner, S., Percevault, F., Demay, F., Bizot, M., LucchettiMiganeh, C., et al. (2011). Epigenetic switch involved in activation of pioneer factor FOXA1-dependent enhancers. Genome Res. 21, 555-565. doi: $10.1101 /$ gr. 111534.110

Shah, N. H., Jonquet, C., Chiang, A. P., Butte, A. J., Chen, R., and Musen, M. A. (2009). Ontology-driven indexing of public datasets for translational bioinformatics. BMC Bioinform. 10 (Suppl. 2), S1. doi: 10.1186/1471-2105-10-S2-S1

Shanafelt, T. D., Drake, M. T., Maurer, M. J., Allmer, C., Rabe, K. G., and Slager, S. L., et al. (2011). Vitamin D insufficiency and prognosis in chronic lymphocytic leukemia. Blood 117, 1492-1498. doi: 10.1182/blood-2010-07-295683

Shi, X. B., Xue, L., Ma, A. H., Tepper, C. G., Kung, H. J., and White, R. W. (2011). miR-125b promotes growth of prostate cancer xenograft tumor through targeting pro-apoptotic genes. Prostate 71, 538-549. doi: 10.1002/pros.21270

Singh, P. K., Preus, L., Hu, Q., Yan, L., Long, M. D., Morrison, C. D., et al. (2014). Serum microRNA expression patterns that predict early treatment failure in prostate cancer patients. Oncotarget 5, 824-840.

Song, G., and Wang, L. (2008). Transcriptional mechanism for the paired miR-433 and miR-127 genes by nuclear receptors SHP and ERRgamma. Nucleic Acids Res. 36, 5727-5735. doi: 10.1093/nar/gkn567

Stamatoyannopoulos, J. A. (2012). What does our genome encode? Genome Res. 22, 1602-1611. doi: 10.1101/gr.146506.112

Stambolsky, P., Tabach, Y., Fontemaggi, G., Weisz, L., Maor-Aloni, R., Siegfried, Z., et al. (2010). Modulation of the vitamin D3 response by cancer-associated mutant p53. Cancer Cell 17, 273-285. doi: 10.1016/j.ccr.2009.11.025 
Strausberg, R. L., Buetow, K. H., Greenhut, S. F., Grouse, L. H., and Schaefer, C. F. (2002). The cancer genome anatomy project: online resources to reveal the molecular signatures of cancer. Cancer Invest. 20, 1038-1050. doi: 10.1081/CNV-120005922

Sun, T., Wang, Q., Balk, S., Brown, M., Lee, G. S., and Kantoff, P. (2009). The role of microRNA-221 and microRNA-222 in androgen-independent prostate cancer cell lines. Cancer Res. 69, 3356-3363. doi: 10.1158/0008-5472.CAN-08-4112

Szeles, L., Poliska, S., Nagy, G., Szatmari, I., Szanto, A., Pap, A., et al. (2010). Research resource: transcriptome profiling of genes regulated by RXR and its permissive and nonpermissive partners in differentiating monocyte-derived dendritic cells. Mol. Endocrinol. 24, 2218-2231. doi: 10.1210/me.2010-0215

Tagami, T., Lutz, W. H., Kumar, R., and Jameson, J. L. (1998). The interaction of the vitamin D receptor with nuclear receptor corepressors and coactivators. Biochem. Biophys. Res. Commun. 253, 358-363. doi: 10.1006/bbrc.1998.9799

Tagliafico, E., Tenedini, E., Manfredini, R., Grande, A., Ferrari, F., Roncaglia, E., et al. (2006). Identification of a molecular signature predictive of sensitivity to differentiation induction in acute myeloid leukemia. Leukemia 20, 1751-1758. doi: 10.1038/sj.leu.2404358

Taylor, D. D., and Gercel-Taylor, C. (2008). MicroRNA signatures of tumor-derived exosomes as diagnostic biomarkers of ovarian cancer. Gynecol. Oncol. 110, 13-21. doi: 10.1016/j.ygyno.2008.04.033

Thorne, J. L., Maguire, O., Doig, C. L., Battaglia, S., Fehr, L., Sucheston, L. E., et al. (2011). Epigenetic control of a VDR-governed feed-forward loop that regulates p21(waf1/cip1) expression and function in non-malignant prostate cells. Nucleic Acids Res. 39, 2045-2056. doi: 10.1093/nar/gkq875

Ting, H. J., Messing, J., Yasmin-Karim, S., and Lee, Y. F. (2013). Identification of microRNA-98 as a therapeutic target inhibiting prostate cancer growth and a biomarker induced by vitamin D. J. Biol. Chem. 288, 1-9. doi: 10.1074/jbc.M112.395947

Towsend, K., Trevino, V., Falciani, F., Stewart, P. M., Hewison, M., and Campbell, M. J. (2006). Identification of VDR-responsive gene signatures in breast cancer cells. Oncology 71, 111-123. doi: 10.1159/000100989

Tress, M. L., Martelli, P. L., Frankish, A., Reeves, G. A., Wesselink, J. J., Yeats, C., et al. (2007). The implications of alternative splicing in the ENCODE protein complement. Proc. Natl. Acad. Sci. U.S.A. 104, 5495-5500. doi: 10.1073/pnas.0700800104

Turner, B. M. (1993). Decoding the nucleosome. Cell 75, 5-8. doi: 10.1016/00928674(93)90673-E

Turner, B. M. (1998). Histone acetylation as an epigenetic determinant of long-term transcriptional competence. Cell Mol. Life Sci. 54, 21-31. doi: 10.1007/s000180050122

Turner, B. M. (2002). Cellular memory and the histone code. Cell 111, 285-291. doi: 10.1016/S0092-8674(02)01080-2

Vaisanen, S., Dunlop, T. W., Sinkkonen, L., Frank, C., and Carlberg, C. (2005). Spatio-temporal activation of chromatin on the human CYP24 gene promoter in the presence of 1alpha,25-Dihydroxyvitamin D3. J. Mol. Biol. 350, 65-77. doi: 10.1016/j.jmb.2005.04.057

Valadi, H., Ekstrom, K., Bossios, A., Sjostrand, M., Lee, J. J., and Lotvall, J. O. (2007). Exosome-mediated transfer of mRNAs and microRNAs is a novel mechanism of genetic exchange between cells. Nat. Cell Biol. 9, 654-659. doi: $10.1038 /$ ncb1596

Varjosalo, M., Keskitalo, S., Van Drogen, A., Nurkkala, H., Vichalkovski, A., Aebersold, R., et al. (2013). The protein interaction landscape of the human CMGC kinase group. Cell Rep. 3, 1306-1320. doi: 10.1016/j.celrep.2013.03.027

Wang, F., Marshall, C. B., and Ikura, M. (2013a). Transcriptional/epigenetic regulator $\mathrm{CBP} / \mathrm{p} 300$ in tumorigenesis: structural and functional versatility in target recognition. Cell. Mol. Life Sci. 70, 3989-4008. doi: 10.1007/s00018-012-1254-4

Wang, J., Huo, K., Ma, L., Tang, L., Li, D., Huang, X., et al. (2011a). Toward an understanding of the protein interaction network of the human liver. Mol. Syst. Biol. 7, 536. doi: 10.1038/msb.2011.67

Wang, Q. M., Jones, J. B., and Studzinski, G. P. (1996). Cyclin-dependent kinase inhibitor p27 as a mediator of the G1-S phase block induced by 1,25dihydroxyvitamin D3 in HL60 cells. Cancer Res. 56, 264-267.

Wang, T. T., Tavera-Mendoza, L. E., Laperriere, D., Libby, E., MacLeod, N. B., Nagai, Y., et al. (2005). Large-scale in silico and microarray-based identification of direct 1,25-dihydroxyvitamin D3 target genes. Mol. Endocrinol. 19, 2685-2695. doi: 10.1210/me.2005-0106
Wang, W. L., Chatterjee, N., Chittur, S. V., Welsh, J., and Tenniswood, M. P. (2011b). Effects of 1alpha,25 dihydroxyvitamin D3 and testosterone on miRNA and mRNA expression in LNCaP cells. Mol. Cancer 10:58. doi: 10.1186/1476-4598$10-58$

Wang, W. L., Welsh, J., and Tenniswood, M. (2013b). 1,25-Dihydroxyvitamin D3 modulates lipid metabolism in prostate cancer cells through miRNA mediated regulation of PPARA. J. Steroid Biochem. Mol. Biol. 136, 247-251. doi: 10.1016/j.jsbmb.2012.09.033

Wang, X., Gocek, E., Liu, C. G., and Studzinski, G. P. (2009). MicroRNAs181 regulate the expression of p27(Kipl) in human myeloid leukemia cells induced to differentiate by 1,25-dihydroxyvitamin $\mathrm{D}(3)$. Cell Cycle 8, 736-741. doi: $10.4161 /$ cc.8.5.7870

Welsh, J., Wietzke, J. A., Zinser, G. M., Smyczek, S., Romu, S., Tribble, E., et al. (2002). Impact of the Vitamin D3 receptor on growth-regulatory pathways in mammary gland and breast cancer. J. Steroid Biochem. Mol. Biol. 83, 85-92. doi: 10.1016/S0960-0760(02)00277-7

Yang, X., Bemis, L., Su, L. J., Gao, D., and Flaig, T. W. (2012). miR-125b Regulation of Androgen receptor signaling via modulation of the receptor complex corepressor NCOR2. Biores. Open Access, 1, 55-62. doi: 10.1089/biores.2012.9903

Yang, X., Downes, M., Yu, R. T., Bookout, A. L., He, W., Straume, M., et al. (2006) Nuclear receptor expression links the circadian clock to metabolism. Cell 126, 801-810. doi: 10.1016/j.cell.2006.06.050

Yuan, C. X., Ito, M., Fondell, J. D., Fu, Z. Y., and Roeder, R. G. (1998). The TRAP220 component of a thyroid hormone receptor- associated protein (TRAP) coactivator complex interacts directly with nuclear receptors in a ligand-dependent fashion. Proc. Natl. Acad. Sci. U.S.A. 95, 7939-7944. doi: 10.1073/pnas.95.14.7939

Zella, L. A., Kim, S., Shevde, N. K., and Pike, J. W. (2006). Enhancers located within two introns of the vitamin $\mathrm{D}$ receptor gene mediate transcriptional autoregulation by 1,25-dihydroxyvitamin D3. Mol. Endocrinol. 20, 1231-1247. doi: 10.1210/me.2006-0015

Zerr, P., Vollath, S., Palumbo-Zerr, K., Tomcik, M., Huang, J., Distler, A., et al. (2014). Vitamin D receptor regulates TGF- $\beta$ signalling in systemic sclerosis. Ann. Rheum. Dis. doi: 10.1136/annrheumdis-2013-204378. [Epub ahead of print].

Zhang, C., Dowd, D. R., Staal, A., Gu, C., Lian, J. B., van Wijnen, A. J., et al. (2003). Nuclear coactivator-62 kDa/Ski-interacting protein is a nuclear matrix-associated coactivator that may couple vitamin D receptor-mediated transcription and RNA splicing. J. Biol. Chem. 278, 35325-35336. doi: 10.1074/jbc.M305191200

Zhang, L., Stokes, N., Polak, L., and Fuchs, E. (2011). Specific microRNAs are preferentially expressed by skin stem cells to balance self-renewal and early lineage commitment. Cell Stem Cell 8, 294-308. doi: 10.1016/j.stem.2011.01.014

Zhang, Y., Szustakowski, J., and Schinke, M. (2009). Bioinformatics analysis of microarray data. Methods Mol. Biol. 573, 259-284. doi: 10.1007/978-1-60761247-6_15

Zhi, H. Y., Hou, S. W., Li, R. S., Basir, Z., Xiang, Q., Szabo, A., et al. (2011). PTPH1 cooperates with vitamin $\mathrm{D}$ receptor to stimulate breast cancer growth through their mutual stabilization. Oncogene 30, 1706-1715. doi: 10.1038/onc.2010.543

Zhou, Y., Gong, W., Xiao, J., Wu, J., Pan, L., Li, X., et al. (2014). Transcriptomic analysis reveals key regulators of mammogenesis and the pregnancy-lactation cycle. Sci. China Life Sci. 57, 340-355. doi: 10.1007/s11427-013-4579-9

Conflict of Interest Statement: The author declares that the research was conducted in the absence of any commercial or financial relationships that could be construed as a potential conflict of interest.

Received: 16 March 2014; accepted: 21 April 2014; published online: 14 May 2014. Citation: Campbell MJ (2014) Vitamin D and the RNA transcriptome: more than $m R N A$ regulation. Front. Physiol. 5:181. doi: 10.3389/fphys.2014.00181

This article was submitted to Integrative Physiology, a section of the journal Frontiers in Physiology.

Copyright (c) 2014 Campbell. This is an open-access article distributed under the terms of the Creative Commons Attribution License (CC BY). The use, distribution or reproduction in other forums is permitted, provided the original author(s) or licensor are credited and that the original publication in this journal is cited, in accordance with accepted academic practice. No use, distribution or reproduction is permitted which does not comply with these terms. 